\title{
Adopsi Teknologi Petani pada Sekolah Lapangan Pengelolaan Tanaman Terpadu (SL-PTT)
}

\section{Adoption of Innovation of Technology by the Farmers in Field School of Comprehensive Agriculture Land-Use Management (SL-PTT)}

\author{
Karmila Muchtar $^{1}$, Djoko Susanto ${ }^{1}$, Ninuk Purnaningsih ${ }^{2}$ \\ ${ }^{1}$ Program Studi Komunikasi Pembangunan Pertanian dan Pedesaan, Sekolah Pascasarjana Institut Pertanian Bogor, Bogor \\ 2 Departemen Sains Komunikasi dan Pengembangan Masyarakat,Fakultas Ekologi Manusia Institut Pertanian Bogor, Bogor
}

\begin{abstract}
Field School of Comprehensive Agriculture Land-Use Management (SL-PTT) is agriculture innovation from ministry of agriculture. The SL-PTT program aims accelerating the adoption of innovation at the farm level to increase production in a sustainable manner. The study aims to analyze decision making process by the farmers to adopt and utilize the technology of rice innovation in their land-use and and how much the production level of rice achieved by the farmers in SL-PTT program. The study was planned using survey descriptive correlational on March-April 2014 covered 80 farmers in village of Abbokongeng, Sub District of Kulo, District of Sidrap, South Sulawesi. Data were analyzed and tested using multiple linear regression. The evidence showed that almost all (91,25\%) of the farmers applied all innovations, such as: using high qualified seeds, planting system, using appropriate fertilizer and water irrigarion, controlling pests, harvest and past-harvest management. Production of

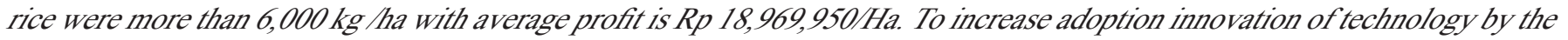
farmers, exntension worker should carry out more intensive approach. Communication between the farmers and the extension worker should be maintained and increased through the SL-PTT program in such that the rice production can be consistently increazed.
\end{abstract}

Keywords: Adoption, technology, farmer, extension worker, SL-PTT

\begin{abstract}
Abstrak
Sekolah Lapangan Pengelolaan Tanaman Terpadu (SL-PTT) merupakan inovasi peningkatan produksi padi dari Kementerian Pertanian. Tujuan utama program SL-PTT adalah percepatan adopsi inovasi di tingkat petani untuk peningkatan produksi secara berkelanjutan. Penelitian ini bertujuan memperoleh gambaran keputusan penerapan teknologi SL-PTT oleh petani dan mengetahui jumlah produksi padi petani peserta program SL-PTT. Penelitian ini berbentuk survei deskriptif korelasional yang dilaksanakan bulan Maret-April 2014 pada 80 petani yang tercatat sebagai peserta program SL-PTT di Desa Abbokongeng, Kecamatan Kulo, Kabupaten Sidrap, Sulawesi Selatan. Pengujian hipotesis menggunakan uji regresi linear berganda. Sebesar 91,3\% petani menerapkan seluruh teknologi, seperti penggunaan benih unggul, penanaman sistem jejer legowo, pemupukan berimbang, pengairan berselang, pengendalian organisme pengganggu tanaman (OPT), panen dan pasca panen. Produksi padi petani lebih dari $6.000 \mathrm{~kg} / \mathrm{ha}$ dengan keuntungan usahatani rata-rata Rp 18.969.950 per hektar. Untuk meningkatkan adopsi inovasi di tingkat petani pada skala yang lebih luas perlu pendekatan yang lebih intensif oleh penyuluh dan melibatkan tutor sebaya untuk menggerakkan petani mengadopsi teknologi secara luas. Komunikasi antara petani dan penyuluh perlu dipertahankan dan ditingkatkan dalam program SL-PTT sehingga peningkatan produksi padi tetap dipertahankan dan dikembangkan.
\end{abstract}

Kata Kunci: Adopsi, teknologi, petani, penyuluh, SL-PTT

\section{Pendahuluan}

Sekolah Lapangan Pengelolaan Tanaman Terpadu(SL-PTT)merupakanprogramdariKementerian Pertanian sebagai inovasi untuk peningkatan produksi padi. SL-PTT adalah wadah pembelajaran bagi petani untuk bertukar informasi, pengetahuan, dan petani merupakan pelaku utama (Lubis, 2007). Tujuan SL-PTT adalah meningkatkan pengetahuan dan keterampilan dalam mengenali potensi, menyusun rencana usaha tani, mengatasi permasalahan, mengambil keputusan dan menerapkan teknologi yang sesuai dengan kondisi sumberdaya setempat. Melalui SL-PTT petani dibimbing secara terpadu dan kerja magang dalam pengelolaan tanaman yang baik dan benar. SL-PTT memberdayakan petani dalam mengelola sumber daya yang tersedia (varietas, tanah, air dan sarana produksi) secara terpadu dalam melakukan budidaya di lahan usahataninya berdasarkan spesifik lokasi sehingga petani menjadi lebih terampil serta mampu mengembangkan usahataninya dalam rangka menghasilkan produktivitas tinggi untuk menunjang peningkatan produksi padi secara 
berkelanjutan. Sama halnya dengan sekolah lapangan sejenis SL-PTT yang berlangsung di Sub-Sahara Afrika memberdayakan petani sebagai ahli teknis sendiri dalam pengelolaan usaha tani. Hasilnya berdampak pada pengurangan pestisida, peningkatan produktivitas, peningkatan pengetahuan petani (Davis, 2008). SL-PTT yang berlangsung pada tahun 2009 sampai saat ini (2014) di Kabupaten Sidrap turut memberikan sumbangsih peningkatan produksi padi yang mampu melampaui target, yakni 457.986 ton pada tahun 2012. Hal ini sejalan dengan Marsudi (2009) bahwa ada perbedaan tingkat efisiensi usaha tani sebelum dan sesudah penerapan program SL-PTT padi. Pencapaian tersebut tidak lepas dari kerja sama antara petani sebagai pelaku utama dan penyuluh sebagai fasilitator. Kompetensi penyuluh mampu mengubah atau mendorong perubahan sehingga pesan yang bersifat inovatif dapat diserap oleh petani sehingga terwujud perbaikan mutu hidup petani. Fachrista \& Risfaheri (2013) menemukan bahwa pendampingan SL-PTT di Bangka Belitung dinilai efektif dalam meningkatkan produktivitas dan pendampingan sehingga mampu memenuhi harapan petani. Penyuluh diharapkan memiliki keahlian dan keterampilan berkomunikasi sehingga dapat mendorong proses belajar yang efektif. Kompetensi penyuluh tersebut dapat mempengaruhi perubahan persepsi dan sikap petani (Anwas, 2009).

Secara umum, penyuluh lapangan berperan sebagai 1) fasilitator yang mengarahkan diskusi, memahami permasalahan, kebutuhan dan kekuatan petani, 2) dinamisator yang menimbulkan ketertarikan dan lebihmenghidupkan proses belajar,3)motivatoryang kaya akan pengalaman dan membantu membangkitkan kepercayaan diri petani, dan 4) konsultan bagi petani peserta SL-PTT untuk mempermudah menentukan langkah-langkah selanjutnya dalam melaksanakan kegiatan usaha taninya. Selanjutnya, monitoring dan evaluasi oleh penyuluh lapangan yang ditujukan untuk mengikuti, mengetahui kemajuan, pencapaian tujuan ataupun sasaran serta memberikan umpan balik upaya-upaya mengatasi permasalahan yang dihadapi. Berdasarkan uraian di atas, maka dianggap penting dalam penelitian untuk: 1) Mengkaji keputusan petani dalam penerapan teknologi dalam program SL-PTT dan 2) Mengkaji jumlah produksi padi petani peserta program SL-PTT.

\section{Metode Penelitian}

Penelitian ini didesain dengan metode survei yang bertujuan untuk mengetahui keputusan petani terkait penerapan teknologi dan jumlah produksi padi petani. Penelitian ini menggunakan pendekatan baik secara kuantitatif maupun kualitatif terhadap 80 responden di Desa Abbokongeng, Kecamatan Kulo, KabupatenSidrap,ProvinsiSulawesi Selatan padabulan Maret-April 2014. Pemilihan responden dilakukan secara sensus dengan mengambil keseluruhan populasi yang terdiri dari empat kelompok tani yang tergabung dalam program SL-PTT, yakni 1) Sibali Resoe 30 anggota, 2) Massimpuloloe 17 anggota, 3) Rijang Ledeng 16 anggota, dan 4) Salo Inru 17 anggota. Data dihimpun melalui kuesioner, FGD, observasi, wawancara langsung baik kepada responden maupun informan. Data yang dikumpulkan dianalisis dengan menggunakan analisis deskriptif, tabel frekuensi dan analisis regresi linear berganda.

\section{Hasil dan Pembahasan}

\section{Keputusan Penerapan Teknologi}

Petani di Desa Abbokongeng berperan aktif dalam proses pengambilan keputusan dalam menerapkan teknologi yang ditawarkan dalam program SL-PTT. Berdasarkan hasil penelitian dan pengamatan di lapangan, petani sepenuhnya menerapkan teknologi dalam SL-PTT (Tabel 1) meliputi:

1) penggunaan benih unggul, keuntungannya adalah benih tumbuh cepat dan serempak, jika disemaikan akan menghasilkan bibit yang tegar dan sehat, pada saat ditanam pindah, bibit tumbuh lebih cepat, dan jumlah tanaman optimum sehingga akan memberikan hasil yang tinggi. 2) penanaman sistem jejer legowo yakni penanaman tepat waktu, serentak dalam populasi optimal. Penanaman yang disarankan menggunakan sistem jajar legowo 2:1 atau 4:1 karena populasi lebih banyak dan produksinya lebih tinggi. Keuntungan cara tanam ini adalah rumpun tanaman yang berada pada bagian pinggir lebih banyak, terdapat ruang kosong untuk pengaturan air, saluran pengumpulan keong mas atau untuk mina padi, pengendalian hama, penyakit, dan gulma lebih mudah, pada tahap awal areal pertanaman lebih terang sehingga kurang disenangi tikus, dan penggunaan pupuk lebih berdaya guna. 3) pemupukan berimbang yakni pemberian berbagai unsur hara dalam bentuk pupuk untuk memenuhi kekurangan hara yang dibutuhkan tanaman berdasarkan tingkat 
Tabel 1 Sebaran responden berdasarkan keputusan penerapan teknologi di Desa Abbokongeng

\begin{tabular}{llccc}
\hline \multirow{2}{*}{ No. } & Keputusan & $\begin{array}{c}\text { Kategori } \\
\text { (Skor) }\end{array}$ & Numlah & \% \\
\hline 1. & Tidak Menerapkan & $1-6$ & 0 & 0,0 \\
2. & Menerapkan sebagian & $7-12$ & 7 & 8,7 \\
3. & Menerapkan sepenuhnya & $13-18$ & 73 & 91,3 \\
\hline Jumlah & & 80 & 100,0 \\
\hline
\end{tabular}

hasil yang ingin dicapai dan hara yang tersedia dalam tanah. Kebutuhan tanaman dapat diketahui dengan cara mengukur tingkat kehijauan warna daun padi menggunakan Bagan Warna Daun (BWD). 4) pengairan berselang, merupakan pengaturan kondisi sawah dalam kondisi kering dan tergenang secara bergantian. Tujuannya adalah memberi kesempatan akar tanaman memperoleh udara lebih banyak sehingga dapat berkembang lebih dalam. Selain itu, pengairan berselang juga memudahkan pengendalian hama serta mengurangi kerusakan tanaman padi karena hama tikus. 5) pengendalian organisme pengganggu tanaman (OPT) dengan menggunakan prinsip dan strategi pengendalian hama terpadu dengan paduan berbagai cara pengendalian hama dan penyakit, di antaranya melakukan monitoring populasi hama dan kerusakan tanaman sehingga penggunaan teknologi pengendalian dapat lebih tepat. 6) panen dan penanganan pasca panen yakni pada umur dan cara yang tepat, secara kelompok menggunakan mesin yang cocok, hasilnya dikemas dalam wadah dan disimpan di tempat yang aman.

Alasan utama petani di Desa Abbokongeng menerapkan sepenuhnya teknologi tersebut karena mampu meningkatkan produksi gabah mencapai 7 ton/hektar. Hanya saja, kendala yang sering dihadapi adalah ketersediaan benih unggul yang terbatas, sehingga petani mengsubtitusi dengan membeli benih lokal yang sesuai selera masyarakat. Rogers (2003) menyatakan bahwa petani umumnya mengadopsi teknologi karena dipengaruhi oleh faktor-faktor berikut:

1) keuntungan relatif yaitu teknologi tersebut lebih menguntungkan dibandingkan dengan teknologi lain. Petani menyadari bahwa teknologi menggunakan benih unggul, tanam jejer legowo, pemupukan berimbang, pengairan berselang, pengendalian hama, dan panen merupakan teknologi yang menguntungkan dibandingkan dengan teknologi lain. Sistem tanam jejer legowo terbukti mampu meningkatkan produksi petani di Desa Abbokongeng. Lokasi berbeda seperti di Desa Pulau Birandang, Kampar Timur petani tidak menggunakan sistem tanam jejer legowo karena petani beranggapan bahwa sistem tanam tersebut mengakibatkan banyak lahan kosong sehingga mengurangi hasil panen. Petani di desa tersebut menggunakan sistem tanam konvensional dengan jarak tanam 22 × $22 \mathrm{~cm}$ (Lestari,dkk, 2012). Hal ini berbeda dengan persepsi petani di Desa Abbokongeng bahwa sistem tanam jejer legowo menambah jumlah produksi karena kehilangan hasil akibat gangguan hama dan penyakit dapat dikendalikan melalui sistem tanam tersebut. Jarak antar tanaman membantu dalam pengendalian hama tikus, karena hama tikus tidak menyukai ruang kosong pada lahan sawah. Di Kabupaten Sidrap sendiri, pemerintah memiliki gerakan Spot Stop yang ampuh mengendalikan hama tikus sampai ke bibit bibitnya.

2) kesesuaian yaitu teknologi tersebut masih konsisten dengan nilai-nilai budaya yang ada. Teknologi yang ditawarkan dalam SL-PTT menurut petani di Desa Abbokongeng telah sesuai dengan budaya masyarakat bugis. Budaya ritual yang dilakukan petani terdahulu sudah ditinggalkan petani sekarang, dengan alasan telah banyak ilmu yang diperoleh dari sekolah lapangan, termasuk penentuan jadwal tanam. Petani di Desa Abbokongen memiliki persepsi bahwa komponen teknologi dalam program SL-PTT memiliki keselarasan dan sangat cocok dengan cara bertani sebelumnya mulai dari seleksi benih sampai penanganan pasca panen serta sesuai dengan kondisi sosial dan ekonomi petani. Hal ini sejalan dengan Indraningsih (2011) bahwa suatu inovasi dapat diterima oleh petani dilihat dari aspek nilai-nilai sosiobudaya, ide-ide yang telah diperkenalkan sebelumnya dan kebutuhan petani akan inovasi.

3) kerumitan yaitu teknologi tersebut mempunyai sifat-sifat yang rumit, sulit dipahami dan 
Tabel 2 Persepsi petani terhadap karakteristik penyuluh di Desa Abbokongeng tahun 2014

\begin{tabular}{lllrr}
\hline \multirow{2}{*}{ No. } & \multirow{2}{*}{ Karakteristik } & Kategori & \multicolumn{2}{c}{ Jumlah } \\
& & (Skor) & n & \% \\
\hline 1. & Penguasaan Materi & Rendah & 0 & 0,0 \\
& & Sedang & 4 & 5,0 \\
& & Tinggi & 76 & 95,0 \\
& & Jumlah & 80 & 100,0 \\
2. Keterampilan Berkomunikasi & Rendah & 0 & 0,0 \\
& & Sedang & 5 & 6,3 \\
& & Tinggi & 75 & 93,7 \\
& & Jumlah & 80 & 100,0 \\
\hline
\end{tabular}

diikuti. Teknologi dalam SL-PTT tidak rumit sehingga lebih mudah diterapkan. Khusus untuk sistem tanam jejer legowo, petani di Desa Abbokongeng dibantu dengan alat tabela sebagai bantuan dari pemerintah. Alat tabela tersebut juga memangkas biaya penggunaan tenaga kerja untuk penanaman. Hal yang menarik di Desa Abbokongeng adalah sikap kerja sama yang sangat kental, petani bersamasama membantu proses penaburan benih. Data yang diperoleh melalui FGD dan wawancara menunjukkan bahwa sebagian besar petani setuju bahwa teknologi dalam SL-PTT mudah dan sederhana sehingga petani mengambil keputusan dengan cepat untuk mengadopsi teknologi tersebut. Namun demikian, teknologi tersebut membantu petani meningkatkan produksi padi secara berkelanjutan.

4) dapat dicoba yaitu ketika teknologi tersebut dapat diuji coba dengan mudah sesuai situasi dan kondisi setempat. Teknologi SL-PTT secara keseluruhan dicoba atau dipraktekkan ke lahan percontohan seluas $1 \mathrm{Ha}$. Di lahan ini petani melihat hasil penerapan teknologi dengan harapan petani menerapkan ke lahan masing-masing. Petani di Desa Abbokongeng menerapkan dan mencoba teknologi SL-PTT langsung di lahan masing-masing tanpa menunggu hasil panen di lahan percontohan. Petani tidak ragu-ragu untuk mengaplikasikan teknologi tersebut langsung pada lahan masing-masing dengan alasan petani percaya sepenuhnya pada penyuluh yang bertugas dan penyuluh mempunyai kepribadian yang ramah dan mampu menciptakan suasana santai dan nyaman untuk berdialog dan bertukar informasi dengan penyuluh sehingga petani yakin dengan keputusan adopsi teknologi. Sejalan dengan petani di Desa Ciulu, Kabupaten Ciamis yang sangat menyukai komponen tanam jejer legowo karena pertanaman terlihat lebih menarik dibandingkan dengan sistem tegel karena memudahkan dalam pemeliharaan, seperti penyiangan, pemupukan, dan sistem tanam jejer legowo tidak terserang oleh hama tikus (Nurawan, 2007). Berbeda dengan petani Di Kabupaten Sumedang, di mana petani belum sepenuhnya melaksanakan pengelolaan tanaman terpadu sesuai anjuran karena petani masih ragu untuk menerima teknologi baru, terutama mencoba sistem tanam jejer legowo (Nurbaeti, dkk, 2010).

5) mudah diamati (observability) yaitu ketika suatu teknologi segera dapat dilihat dan dirasakan hasilnya. Petani dalam hal ini mudah mengamati hasil-hasil, keuntungan-keuntungan dan kelebihan dari teknologi SL-PTT dibandingkan dengan teknologi lain. Hasil wawancara menunjukkan petani yang telah lama bertani mengaku senang menggunakan teknologi sekarang dibandingkan cara bertani terdahulu karena melihat jumlah produksi yang bertambah dan tingkat kesuburan tanaman meningkat. Petani mampu menghasilkan produksi dari 5 ton/ha menjadi 6-7 ton/ha untuk setiap musim tanam. Senada dengan petani padi sawah di Bangka Belitung yang tergabung dalam program SL-PTT merasakan peningkatan produktivitas mencapai 1,13 ton/ha pada tahun 2010 (Fachrista, dkk, 2013).

Penerapan teknologi petani di wilayah Desa Abbokongeng yang tergolong tinggi tidak lepas dari peran aktif penyuluh pertanian sebagai fasilitator. Penyuluh pertanian dan petani memiliki hubungan akrab selayaknya keluarga sendiri. Hal ini disebabkan penyuluh pertanian adalah penduduk setempat dengan budaya dan bahasa yang sama, sehingga petani dapat leluasa berdialog dengan bahasa daerah setempat 
Tabel 3 Analisis usahatani responden di Desa Abbokongeng

\begin{tabular}{|c|c|c|c|c|}
\hline \multirow{2}{*}{ No. } & \multirow{2}{*}{$\begin{array}{c}\text { Karakteristik } \\
\text { Responden }\end{array}$} & \multirow{2}{*}{ Kategori (tahun/kg/rp) } & \multicolumn{2}{|c|}{ Jumlah } \\
\hline & & & $\mathbf{n}$ & $\%$ \\
\hline \multirow[t]{6}{*}{1.} & Aktif SL-PTT & 2009 & 42 & 52,5 \\
\hline & & 2010 & 8 & 10,0 \\
\hline & & 2011 & 13 & 16,2 \\
\hline & & 2012 & 9 & 11,3 \\
\hline & & 2013 & 8 & 10,0 \\
\hline & & Jumlah & 80 & 100,0 \\
\hline \multirow[t]{4}{*}{2.} & Produksi & $<3.000 \mathrm{~kg} / \mathrm{ha}$ & 5 & 6,3 \\
\hline & & $3.000 \mathrm{~kg} / \mathrm{ha}-6.000 \mathrm{~kg} / \mathrm{ha}$ & 18 & 22,5 \\
\hline & & $>6.000 \mathrm{~kg} / \mathrm{ha}$ & 57 & 71,2 \\
\hline & & Jumlah & 80 & 100,0 \\
\hline \multirow[t]{5}{*}{3.} & Keuntungan & $<\mathrm{Rp} 8 \mathrm{jt}$ & 6 & 7,5 \\
\hline & & $\mathrm{Rp} 8 \mathrm{jt}-\mathrm{Rp} 18 \mathrm{jt}$ & 11 & 13,8 \\
\hline & & $>\mathrm{Rp} 18 \mathrm{jt}$ & 63 & 78,7 \\
\hline & & Jumlah & 80 & 100,0 \\
\hline & & Rata-Rata & & Rp18.969.950 \\
\hline
\end{tabular}

(bahasa bugis). Selain itu, penyuluh pertanian memiliki kepribadian yang ramah dan kemampuan berkomunikasi yang mampu menciptakan suasana santai, terbuka, dan nyaman untuk berdialog. Petani memiliki tingkat kepercayaan yang tinggi terhadap penyuluh lapangan yang bertugas di Desa Abbokongeng.

Penyuluh pertanian berdasarkan amanat UU No. 16 tahun 2006 tentang Sistem Penyuluhan Pertanian, Perikanan, dan Kehutanan, penyuluh pertanian dituntutmemilikikompetensi untuk: Pertama, mengerjakan suatu tugas atau pekerjaan penyuluhan dengan terampil untuk memberdayaan orang-orang dalam upaya meraih kesejahteraan diri, keluarga dan masyarakatnya. Kedua, mengorganisasikan sistem penyuluhan sehingga efektif memfasilitasi masyarakat dengan cermat agar masyarakat dapat memenuhi kebutuhannya secara mandiri. Ketiga, melakukan tindakan yang tepat bilamana terjadi sesuatu yang berbeda dengan rencana penyuluhan semula. Keempat, bagaimana menggunakan kemampuan yang dimilikinya untuk memecahkan masalah atau melaksanakan tugasnya sebagai penyuluh meski dengan kondisi yang berbeda (lokal spesifik). Kelima, mampu mensinergikan kepentingan lokal dengan kepentingan yang lebih luas (Sumardjo, 2008). Berdasarkan hasil pengamatan, persepsi petani terhadap penyuluh pertanian yang bertugas di Desa Abbokongeng adalah sebagai berikut:

Penyuluh lapangan di Desa Abbokongeng memiliki karakteristik sebagai berikut: Pertama, dari segi penguasaan materi, penyuluh aktif berdiskusi mengenai materi SL-PTT dengan petani sehingga petani merasa terpanggil untuk aktif dalam proses belajar SL-PTT. Adapun materi SL-PTT diperoleh penyuluh lapangan melalui pelatihan di Kota Makassar dan di Kota Malang. Selain itu, penyuluh lapangan yang bertugas di Kecamatan Kulo aktif berbagi pengetahuan dan pengalaman dengan penyuluh yang berasal dari kecamatan Lain.

Kedua, pengalaman/masa kerja penyuluh: penyuluh lapanganyang bertugas diDesaAbbokongeng telah mendampingi petani selama 3 (tiga) tahun mampu menjalin kedekatan atau hubungan individu yang kuat, hal ini tidak saja dengan petani yang terlibat dalam SLPTT tetapi dengan petani lain di luar SL-PTT. Kondisi 
Tabel 4 Karakteristik petani program SL-PTT di Desa Abbokongeng tahun 2014

\begin{tabular}{|c|c|c|c|c|}
\hline \multirow{2}{*}{ No. } & \multirow{2}{*}{ Karakteristik } & \multirow{2}{*}{$\begin{array}{c}\text { Kategori } \\
\text { (tahun/ha) } \\
\end{array}$} & \multicolumn{2}{|c|}{ Jumlah } \\
\hline & & & $\mathbf{n}$ & $\%$ \\
\hline \multirow[t]{4}{*}{1.} & Umur & Muda (18 - 29) & 9 & 11,2 \\
\hline & & Dewasa (30 - 49) & 45 & 56,3 \\
\hline & & Tua $(\geq 50)$ & 26 & 32,5 \\
\hline & & Jumlah & 80 & 100,0 \\
\hline \multirow[t]{4}{*}{2.} & Tingkat Pendidikan & Rendah $(0-6)$ & 35 & 43,7 \\
\hline & & Sedang $(7-12)$ & 43 & 53,7 \\
\hline & & Tinggi $(>12)$ & 2 & 2,6 \\
\hline & & Jumlah & 80 & 100,0 \\
\hline \multirow[t]{4}{*}{3.} & Pengalaman Berusahatani & Baru (<5 tahun) & 5 & 6,3 \\
\hline & & Sedang (5 - 20 tahun) & 29 & 36,2 \\
\hline & & Lama (> 20 tahun $)$ & 46 & 57,5 \\
\hline & & Jumlah & 80 & 100,0 \\
\hline \multirow[t]{4}{*}{4.} & Luas Lahan & Sempit $(<0,5$ ha $)$ & 3 & 3,7 \\
\hline & & Sedang $(0,5 \mathrm{ha}-2 \mathrm{ha})$ & 69 & 86,3 \\
\hline & & Luas ( $>2$ ha) & 8 & 10,0 \\
\hline & & Jumlah & 80 & 100,0 \\
\hline \multirow[t]{4}{*}{5.} & Status Sosial & Milik Sendiri & 28 & 35,0 \\
\hline & & Penggarap & 21 & 26,3 \\
\hline & & Bagi Hasil & 31 & 38,7 \\
\hline & & Jumlah & 80 & 100,0 \\
\hline
\end{tabular}

ini menjadi indikator penting yang menumbuhkan dan membangkitkan semangat berkomunikasi petani.

Ketiga, keterampilan berkomunikasi penyuluh: penyuluh pertanian lapangan di Desa Abbokongeng selalu mengedepankan prinsip saling berbagai pengetahuan dan informasi dengan petani. Penyuluh memerlukan pertukaran informasi dengan petani untuk mewujudkan tujuan yang sama, yakni peningkatan produksi padi. Hal ini mengindikasikan bahwa penyuluh pertanian berusaha mensejajarkan posisi denga petani sebagai pelaku utama. Sumardjo (2007) menyatakan bahwa keberadaan dan kemampuan petani yang dikenali, dihargai atau menempatkan martabat petani secara lebih layak akan mendorong komunikasi partisipatif petani yang tinggi.

\section{Jumlah Produksi Padi Petani}

Petani di Desa Abbokongeng aktif mengikuti kegiatan SL-PTT sejak program ini diluncurkan Kementerian Pertanian pada tahun 2009. Adapun jenis bantuan yang diterima petani dari program sekolah lapangan adalah benih unggul, pupuk (kompos, urea, pelangi, pitrobio), pestisida, dan alat tabela (tanam benih langsung). Produksi gabah petani di Desa Abbokongeng lebih dari $6.000 \mathrm{~kg} /$ ha dengan keuntungan usahatani rata-rata $\mathrm{Rp}$ 18.969.950 per hektar. Penjualan gabah hasil panen tidak susah karena langsung dijual kepada pedagang/ pengumpul dengan harga bervariasi mulai dari $\mathrm{Rp}$ $3.300 / \mathrm{kg}-\mathrm{Rp} 3.500 / \mathrm{kg}$.

Hasil produksi yang cukup tinggi di Desa Abbokongen masih menyisakan beberapa permasalahan produksi seperti: 1) Bantuan benih dari pemerintah terkadang tidak cukup dan sering terlambat sehingga petani terpaksa membeli benih lokal dengan harga mahal ( $\operatorname{Rp~3.500/kg),~2)~Ketersediaan~pupuk,~}$ sama halnya dengan benih, pupuk dari pemerintah tidak cukup dan sering terlambat sehingga petani menutupi kekurangan dengan membeli sendiri. Biaya yang dikeluarkan pun beragam karena petani membayar bunga pinjaman dari pupuk dan pestisida yang dibayar setelah panen, 3) Air irigasi yang digunakan petani tergolong sangat lancar, bahkan terkadang masalah muncul karena kelebihan air/ irigasi sehingga pintu sekunder irigasi sulit tertutup dan membajiri sawah yang dekat dengan saluran 


\section{Jumlah Produksi (ton)}

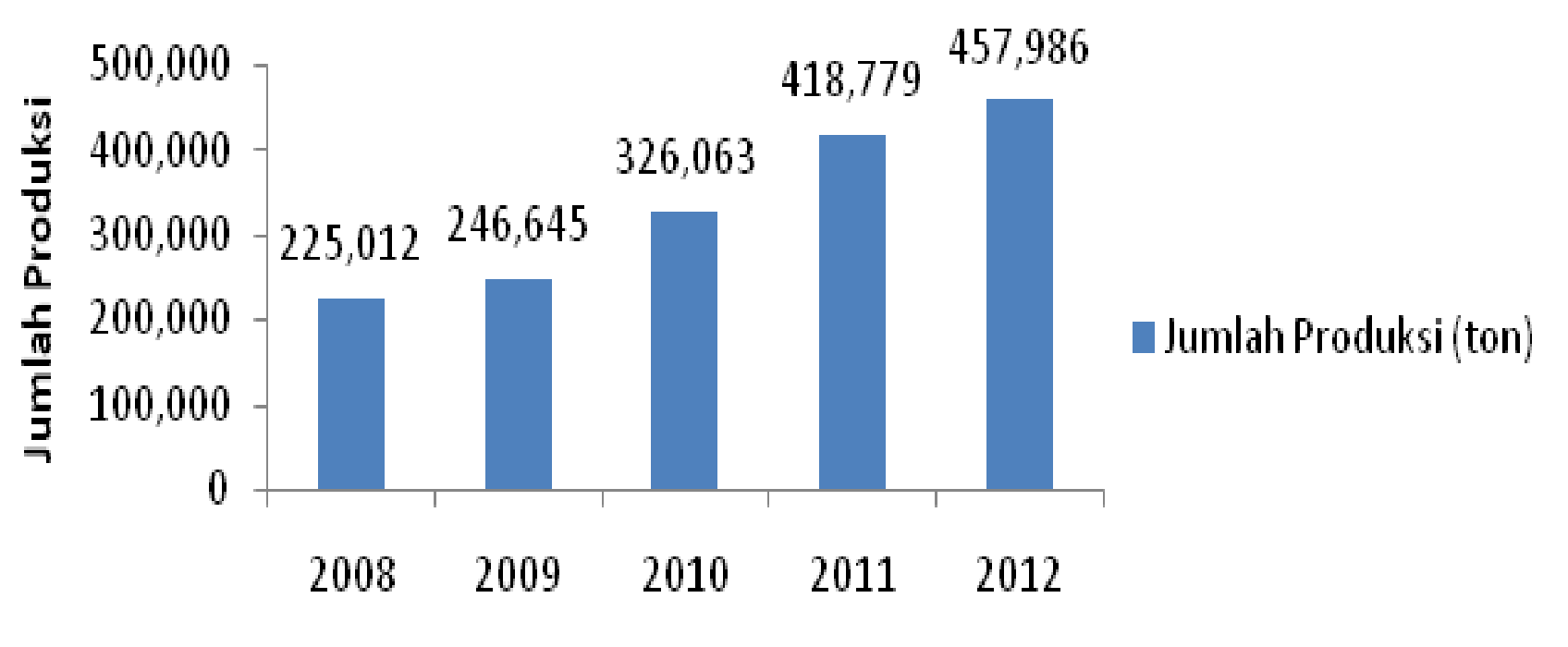

Gambar 1 Jumlah produksi padi di Kabupaten Sidrap tahun 2008 - 2012

irigasi, 4) Serangan hama dan penyakit merupakan masalah utama petani, hama yang sering muncul adalah tikus dan penggerek batang. Wawancara dengan salaha satu petani menyatakan "mengalami peningkatan produksi setelah mengikuti kegiatan SL-PTT dari 5 ton/hektar menjadi 7 ton/hektar dengan keuntungan bisa mencapai Rp 21.210.000. Peningkatan produksi tersebut berhubungan dengan SL-PTT karena adanya bantuan pupuk dan benih, Kata Pak M (53 tahun)". Melalui pendekatan partisipatif dalam program SL-PTT juga membantu petani meninggalkan cara berusahatani yang lama, "Pak A (29 tahun) adalah ketua kelompok tani Sibali Resoe telah meninggalkan cara berusahatani secara turun temurun karena banyak belajar cara bertani melalui SL-PTT. Peningkatan produksi yang dicapai karena adanya bantuan teknologi berupa alat tabela (tabur benih langsung). Keuntungan produksi yang dicapai Pak A sebesar Rp 23.220.000”.

Hama pada tanaman padi umumnya adalah serangan hama tikus, penggerek batang, wereng coklat, dan sejumlah jenis organisme pengganggu tanaman (OPT) lainnya yang selama ini menjadi musuh utama petani. Selain itu, pihak petani juga mendapatkan sejumlah kemudahan yang diberikan oleh Dinas Pertanian dan Perkebunan setempat. Misalnya, sebagai langkah antisipasi pengembangbiakan hama tikus, Dinas Pertanian Sidrap telah melalukan gerakan Spot Stop yang sangat ampuh untuk mengendalikan hewan pengerat ini hingga ke bibit-bibitnya. Data riil di Kabupaten Sidrap menyatakan bahwa melalui penerepan teknologi sistem tanam jajar legowo mampu menghasilkan produksi hingga 8,7 juta ton/ ha Gabah Kering Panen (GKP) pada tahun 2011 lalu (BPKP, 2011). Lebih khusus di Kabupaten Sidrap, harapan besar disandarkan kepada para penyuluh pertanian sebagai ujung tombak sekaligus jembatan informasi dan teknologi yang dibutuhkan oleh petani, dengan harapan bisa memberikan kontribusi bagi surplus Cadangan Beras Nasional 2014 yakni 10 Juta Ton.

Desa Abbokongeng adalah salah satu desa yang turut menyumbang produksi padi di Kecamatan Kulo secara khusus dan Kabupaten Sidrap secara umum. Petani di desa ini memiliki karakteristik petani yang aktif dan ulet. Petani di Desa Abbokongeng memiliki karakteristik sebagai berikut:

Mayoritas petani yakni sebesar 56,3\% berada pada kisaran umur 30-49 tahun. Hal ini menunjukkan bahwa sebagian besar petani berada pada usia produktif. Usia produktif memungkinkan petani ikut serta dan terlibat aktif dalam program SL-PTT, serta memiliki kemampuan menyerap berbagai informasi dan inovasi dalam berusahtani. Usia produktif tersebut sejalan dengan tingkat pendidikan formal petani yakni $53,7 \%$ menamatkan pendidikan sampai jenjang SMP dan SMA.

Pengalaman berusahatani responden tergolong 
Tabel 5 Pengaruh penerapan komunikasi dua arah terhadap keputusan penerapan teknologi

\begin{tabular}{lccc}
\hline \multirow{2}{*}{ Penerapan Teknologi } & \multicolumn{3}{c}{ Proses Penerapan Komunikasi Dua Arah } \\
& Koefisien regresi & t & Signifikan \\
\hline Constant & 16,930 & 4,640 & 0,000 \\
Penerapan Sepenuhnya & 0,126 & 2,410 & $0,049^{* *}$ \\
\hline
\end{tabular}

Keterangan: ** sangat nyata pada taraf $\alpha 0.01$

lama, yakni 57,5\% telah berusahatani lebih dari 20 tahun. Semakin berpengalaman petani dalam berusahatani, mereka semakin tahu, cermat, dan memahami berbagai masalah yang berkaitan dengan pengelolaan usahatani. Pengetahuan dan keterampilan petani didapatkan dari proses belajar yang lama, baik secara turun temurun dari orang tua maupun dari sesama petani. Adapun luas lahan petani antara 0,5 ha-2 ha sekitar $86,3 \%$ dengan status sosial responden beragam dengan status kepemilikan lahan milik sendiri, petani penggarap, dan sistem bagi hasil.

Karakteristik petani yang tergolong tinggi menjadi salah satu faktor pendukung dalam peningkatan produksi padi setiap tahunnya. Produksi padi rata-rata petani adalah 6-7 ton per hektar. Secara umum, Kabupaten Sidrap merupakan penghasil padi terbesar di Provinsi Sulawesi Selatan, bahkan bapak Presiden RI baru-baru ini, tepatnya bulan Februari 2014 turut melakukan panen raya di kota lumbung padi ini.

Pemerintah Kabupaten Sidrap banyak melakukan kajian dan pembenahan terhadap bidang pertanian sehingga mampu mencapai swasembada beras di Sulawesi Selatan. Hal ini sesuai dengan visi Kabupaten Sidrap yakni mewujudkan Sidrap sebagai pusat agribisnis modern dan lima terbaik di Sulawesi dalam pembangunan manusia dengan meningkatkan produktivitas dan juga nilai tambah agrobisnisagroindustri.

Selain karakteristik petani yang tinggi, peningkatan produksi padi juga dipengaruhi oleh proses belajar petani dengan penyuluh pertanian. Seorang petani menyatakan bahwa "peningkatan produksi saya capai karena saya terbuka untuk informasi dan pengetahuan, saya senang belajar dari petani yang sudah lama dan dari penyuluh, kata Pak P.S (28 tahun)". Petani aktif berdiskusi dengan penyuluh lapangan. Analisis statistik menunjukkan bahwa komunikasi yang bersifat dua arah dalam program SL-PTT berpengaruh secara nyata terhadap adopsi teknologi petani. Komunikasi yang efektif antara petani dan penyuluh pertanian menjadi jembatan bagi petani untuk mengambil keputusan penerapan teknologi di lahan sawah masing-masing. Komunikasi dua arah berpengaruh sangat nyata terhadap keputusan penerapan teknologi petani program SL-PTT. Artinya, semakin aktif komunikasi antara petani dan penyuluh, maka semakin tinggi pula adopsi teknologi di tingkat petani. Petani mengambil keputusan untuk mengadopsi teknologi PTT diasumsikan disebabkan oleh hasil panen di laboratorium lapangan (LL) dan faktor internal petani itu sendiri. Petani memiliki motivasi tinggi untuk meningkatkan produksi. Hal tersebut mendapat dukungan dari pemerintah daerah, petani mendapat dukungan dari para pemangku kepentingan. Salah satu proses belajar petani dalam program SLPTT dihadiri oleh Wakil Bupati Kabupaten Sidrap yang berpartisipasi dalam pemenuhan kebutuhan petani. Tujuan pemerintah daerah sama dengan tujuan petani yakni untuk meningkatkan produksi secara berkelanjutan. Petani diberi ruang untuk menciptakan suasana yang nyaman, terbuka, bebas dari tekanan, serta diberi akses dan kesempatan untuk memanfaatkan media komunikasi yang ada.

Komunikasi tatap muka menjadi alternatif utama dan efektif yang dirasakan petani dan penyuluh pertanian. Petani dan penyuluh pertanian biasanya duduk berdiskusi di rumah petani untuk membahas kendala dan kebutuhan untuk mencapai kesepakatan bersama. Penyuluh pertanian dan petani biasanya dimulai pada pukul 09.00 WITA sampai sore hari. Hal ini adalah waktu yang sangat efektif mengingat petani di Desa Abbokongeng bertani pada pagi hari. Topik pembicaraan seputar pengelolaan usahatani mengalir begitu saja sehingga petani tidak terbebani dan merasa nyaman dalam berdiskusi. Penyuluh juga tidak memberatkan petani yang rumahnya menjadi tempat berdialog karena tiba jam makan siang, penyuluh akan kembali ke kantor balai penyuluhan pertanian untuk beristirahat sejenak.

Jarak antara persawahan dengan rumah petani 
tidak menjadi hambatan untuk berpartisipasi dalam setiap dialog SL-PTT. Hal ini karena sawah petani terletak di areal pemukiman penduduk dan disertai prasarana jalan yang memadai. Gambaran komunikasi partisipatif yang terjadi di Desa Abbokongen telah memenuhi strategi komunikasi menurut Dagron (2001) bahwa dialog yang terjadi berbasis komunitas petani dan cara-cara komunikasi merupakan jalan utama untuk membantu mengidentifikasi kebutuhan petani, bukan berdasarkan kehendak dan kepentingan golongan tertentu. Selain itu, penyuluh pertanian berusaha melakukan proses penyadaran dan pemahaman kepada petani tentang masalah dan pencarian solusi, bukan secara persuasi yang hanya berdampak mengubah perilaku jangka pendek.

Penyuluh pertanian yang bertugas di Desa Abbokongeng memiliki beberapa syarat sebagai seorang komunikator menurut Belch dan Belch (2001). Syarat-syarat tersebut adalah: 1) memiliki keahlian, pengetahuan, keterampilan dan pengalaman, 2) memiliki kejujuran yakni tingkat kepercayaan terhadapniatkomunikator dalammengkomunikasikan penilaian yang dianggapnya paling benar, 3) memiliki daya tarik, daya tarik bukan dilihat dari kecantikan fisik saja melainkan juga berbagai sifat dan karakter yang dimiliki oleh penyuluh, misalnya kemampuan intelektual, kepribadian, gaya hidup dan sebagainya. Seorang fasilitator memiliki nilai tambah berupa kekaguman dari banyak orang. Penampilan seseorang dalam berkomunikasi akan mempengaruhi proses komunikasi yang dilakukannya. Dalam kaitan dengan kredibilitas sumber pesan, pengaruh penampilan terutama pada kontak pertama antara sumber dan penerima pesan, 4) memiliki keakraban dengan petani, keakraban penting karena lebih memperhatikan aspek kesamaan dan daya tarik penyuluh sebagai sumber komunikasi.

Sepanjang pengamatan di lapangan, proses adopsi teknologi petani di Desa Abbokongeng disebabkan oleh beberapa faktor : 1) motivasi petani yang tinggi untuk terus-menerus melakukan proses belajar untuk meningkatkan produksi setiap musim tanam, 2) sikap penyuluh pertanian yang terbuka dan rela berbagi kekuasaan dengan petani, artinya penyuluh berusaha menyejajarkan kedudukan dengan petani. Selain itu, penyuluh yang berasal dari penduduk setempat yang menguasai bahasa daerah menjadi tonggak penting dalam proses komunikasi yang efektif, 3) komitmen pemerintah daerah untuk mempertahankan predikat sebagai penyangga beras terbesar di Sulawesi Selatan sehingga berusaha memenuhi kebutuhan petani, bahkan pemerintah daerah mempunyai harapan sebagai penyangga beras di Indonesia bagian timur.

\section{Kesimpulan}

Berdasarkan hasil pembahasan di atas, kesimpulan dalam penelitian ini sebagai berikut: Pertama, petani memutuskan menerapkan sepenuhnya yakni sebesar 91,3\% teknologi SL-PTT. Hal ini disebabkan teknologi tersebut bermanfaat untuk peningkatan produksi padi secara berkelanjutan. Kedua, produksi padi petani di Desa Abbokongeng mencapai 7 ton/ha dengan rata-rata keuntungan $\mathrm{Rp}$ 18.969.950.

Partisipasi petani harus ditingkatkan melalui pendekatan yang lebih intensif oleh penyuluh pertanian. Misalnya, membentuk kelompok kecil untuk diskusi terfokus dengan petani yang terbuka pada inovasi dan perubahan sehingga menjadi contoh bagi petani yang belum menerapkan teknologi dalam program SL-PTT. Diharapkan bahwa seluruh petani dapat menerapkan teknologi SL-PTT melalui peran aktif penyuluh dan komunikasi interaktif antar sesama petani. Penyuluh juga bisa melibatkan tutor sebaya untuk menggerakkan petani mengadopsi teknologi PTT secara luas.

\section{Daftar Pustaka}

Anwas EOM. 2009. Pemanfaatan Media dalam Pengembangan Kompetensi Penyuluh Pertanian (Kasus di Kabupaten Karawang dan Garut, Jawa Barat). [disertasi]. Bogor (ID): Institut Pertanian Bogor.

Badan Penyuluhan dan Ketahanan Pangan Kabupaten Sidrap. 2011. Sidenreng Rappang Optimis Mewujudkan Target Surplus 10 Juta Ton Beras 2014 melalui Kegiatan Pengawalan di Lokasi SL-PTT. [Internet]. [dapat diunduh dari http://cybex.deptan.go.id].

Belch, George E, Belch, Michael A. 2001. Advertising and promotion: an integrated marketing communication perspective. New York (US): McGrew Hill Companies.

Davis KE. 2008. Extension in Sub-Sahara Africa: Overview and Assessment of Post and 
Current Model, and Future Prospects. Journal of International Agricultural and Extension Education 15(3). Association of International Agricultural and Extension Education.

Dagron GA. 2001. Making waves: stories of participatory communication for social change: Participatory Communication Case Studies. Rockefeller Foundation.

Fachrista, Audiah, Risfaheri. 2013. Strategi pengembangan pendampingan sekolah lapang pengelolaan tanaman terpadu (SL-PTT) padi sawah di Bangka Belitung. Jurnal Balai Pengkajian Teknologi Pertanian Kepulauan Bangka Belitung 9 (2).

Indraningsih KS. 2011. Pengaruh penyuluhan terhadap keputusan petani dalam adopsi inovasi teknologi usahatani terpadu. Jurnal Agro Ekonomi, 29 (1).

Lestari W, Rabesdini, Yusri. 2012. Respon petani terhadap program sekolah lapang pengelolaan tanaman terpadu (SL-PTT) Padi Sawah di Desa Pulau Birandang, Kampar Timur. Fakultas Pertanian, Universitas Riau.

Lubis D. 2007. Komunikasi menuju Komunitas Pembelajar. Editor: Adiwibowo, S. Ekologi Manusia. Bogor(ID): Fakultas Ekologi Manusia. Marsudi. 2009. Evaluasi Petani Peserta Program Sekolah Lapangan Pengelolaan Tanaman
Terpadu (SL-PTT) Padi di Kabupaten Ngawi. [tesis]. Program Pascasarjana Universitas Pembangunan Nasional "Veteran" Jawa Timur.

Nurawan A. 2007. Peningkatan produksi padi dengan pendekatan model pengelolaan tanaman terpadu, analisis usahtani dan respons petani terhadap komponen teknologi ptt padi. Apresiasi Hasil Penelitian Padi. Balai Pengkajian Teknologi Pertanian Jawa Barat.

Nurbaeti B, Muljanti, Fahmi. 2010. Penerapan model pengelolaan tanaman dan sumberdaya terpadu padi sawah irigasi di kabupaten sumendang. Jurnal Pengkajian dan Pengembangan Teknologi Pertanian 11(3).

Rogers. 2003. Diffusion of Innovation. 4th ed. New York (NY): Free Press: A Division of Simon \& Schuster, Inc.

Sumardjo. 2007. Komunikasi dalam perspektif ekologi manusia. Editor: Adiwibowo, S. Ekologi Manusia. Bogor (ID): Fakultas Ekologi Manusia, Institut Pertanian Bogor.

Sumardjo. 2008. Penyuluhan pembangunan: pilar pendukung kemajuan dan kemandirian masyarakat. dalam pemberdayaan manusia pembangunan yang bermartabat. penyunting: adjat sudrajat dan ida yustina. Bogor (ID): Sydex Plus. 